\title{
ATPase Family AAA Domain-Containing Protein 5
}

National Cancer Institute

\section{Source}

National Cancer Institute. ATPase Family AAA Domain-Containing Protein 5. NCI

Thesaurus. Code C114948.

AT Pase family AAA domain-containing protein 5 (1844 aa, $208 \mathrm{kDa}$ ) is encoded by the human ATAD5 gene. This protein is involved in the DNA damage checkpoint. 